\title{
Identificación de Lenguaje Metafórico en textos argumentativos en inglés como lengua extranjera: un estudio de corpus
}

\author{
Metaphor Identification in EFL Argumentative \\ Writing: A Corpus-driven Study
}

Claudia Marcela Chapetón1

\section{Abstract}

This article reports research investigating instances of linguistic metaphor in contextualized corpus data. Since the issue of metaphor identification in naturally-occurring data has been reason of current debate among cognitive and applied linguists, this paper focuses particularly on the process of identification of this type of language in corpus data and proposes a combined procedure for metaphor identification. The findings inform about the presence and word class of metaphorical language in the argumentative writing of EFL university students. Implications and directions for future research are highlighted.

\section{Keywords}

Linguistic metaphor, corpus linguistics, metaphor identification procedures, EFL students' metaphor production

\section{Resumen}

Este artículo reporta un estudio de instancias de lenguaje metafórico en datos contextualizados enmarcados en la lingüística del corpus. Dado que el problema de la identificación del lenguaje metafórico se ha constituido como causa de debate entre estudiosos de la lingüística cognitiva y la lingüística aplicada, este artículo se enfoca principalmente en los procesos de identificación de este tipo de lenguaje en datos auténticos de corpus, y propone un procedimiento combinado aplicable a este tipo de análisis. Los resultados informan acerca de la presencia del lenguaje metafórico y su clasificación gramatical en textos argumentativos escritos por estudiantes universitarios de inglés como lengua extranjera. El artículo discute las implicaciones de este estudio y propone posibles direcciones para futuras investigaciones.

\section{Palabras clave}

Metáfora lingüística, lingüística del corpus, procedimientos de identificación de metáfora, producción metafórica de estudiantes de inglés como lengua extranjera.

Artículo recibido el 5 de Mayo de 2010 y aprobado el 30 de Agosto de 2010

1 Profesora de planta del Departamento de Lenguas, Facultad de Humanidades, Universidad Pedagógica Nacional, Colombia. Doctora en Lingüística Aplicada, Universidad de Barcelona, España. cmchapeton@ gmail.com 
Speaking in pictures is common to all languages, modern and ancient, no matter how highly advanced or primitive they may be. And it is by no means a privileged domain of the master speaker or the poet.

As a matter of fact, we all employ the medium of figurative speech,

and we do so unconsciously, not aware of the metaphors, domestic

and borrowed, which accompany and enrich even our plain everyday talk.

Hugh J. Liebesny (1957)

\section{Introduction}

Etymologically speaking, the word metaphor comes from the Middle English methaphor, from Old French metaphore, from Latin metaphora and, in Greek it derives from meta-phora for 'carry across' (Deutscher, 2005). According to The Oxford Dictionary of English (2005), it derives from Greek metapherein which means 'to transfer'. From these simple roots, metaphor has come to mean different things to different people.

Generally speaking, theories of metaphor in different areas of knowledge such as philosophy, linguistics, psychology, literature, anthropology and sociology, address one or more aspects of these two major senses of metaphor: metaphor as a form of linguistic expression and communication and metaphor as a form of conceptual representation and symbolization. However, as Glucksberg (2001) points out, metaphor challenges definition for at least two reasons. First, the term is used in various, though related, senses; and second, definitions differ to reflect sharply different theoretical agendas and assumptions.

Theoretical work on metaphor led by Lakoff \& Johnson (1980) and Lakoff $(1987,1993)$ has argued that metaphor goes beyond the decorative and poetic. Their work has highlighted that metaphor is not just a 'pleasing linguistic ornament' or 'a device of the poetic imagination', but a process of human thought and reasoning. In their view, metaphor has purposes beyond the artistic or aesthetic since it helps to better understand certain abstract concepts and thus, it has the great potential of influencing the way people think, reason, and imagine in everyday life.

Metaphorical expressions, as Lakoff and colleagues point out, are used effortlessly in everyday life by ordinary people to make manifest the concepts underlying our everyday understanding of events and experiences. Lakoff \& Johnson (1980) also suggest that since metaphors result from our clearly delineated and concrete experiences, they play a key role in helping us to construct and structure, at the conceptual level, highly abstract and elaborate concepts.

Within this cognitive trend, metaphor consists of two domains or semantic areas: the target domain, typically abstract, and the source domain, typically concrete. The target domain is the idea or concept expressed by a metaphor or talked of metaphorically while the source domain is the idea or concept used to figuratively understand and express that target. This cognitive approach has shown that metaphor is pervasive in different registers and that it can be highly systematic.

The fact that most metaphorical linguistic expressions used as evidence to support these theoretical claims come from constructed, idealized or elicited, and decontextualized cases, has resulted in a shift in focus in the metaphor research agenda. With the development of discourse and corpus approaches to metaphor, the need to apply cognitive metaphor theory (CMT) to empirical, naturally-occurring discourse data has been highlighted and has developed a more applied linguistic approach to the study of metaphor (e.g., Cameron \& Low, 1999; CharterisBlack, 2004; Deignan, 2005; Semino, 2008; Steen, 1999; Zanotto, Cameron, \& Cavalcanti, 2008).

This applied linguistic trend has focused on the language used by people in particular, real-world contexts, using empirical corpus data from different types of oral and written discourse, and voicing a growing concern about the methodological procedures for metaphor identification in authentic data.

Despite the recognition of metaphor as ubiquitous and relevant in both cognition and language, 
the ability of foreign language learners to make use of metaphorical language in their everyday (academic) life is often still not seen as a core ability (Littlemore \& Low, 2006). This ability has been referred to as 'metaphoric competence' (e.g., Littlemore, 2001; Littlemore \& Low, 2006) or as 'conceptual fluency' by Danesi $(1993,1994)$.

In her definition of metaphoric competence, Littlemore (2001) includes one important component, namely "originality of metaphor production" which as she argues, is important for foreign language learners since it is likely to contribute to their overall communicative language ability. The focus of this corpus-driven study is placed on this aspect related to metaphor production which Littlemore refers to as "the ability to think up one's own unconventional metaphors" (Littlemore, 2001, p. 461). A further aspect of metaphor production will be investigated in this study in that not only unconventional metaphor is at the core, but also, and equally important, is the use of conventional, entrenched metaphorical language. ${ }^{2}$

The present research takes an applied linguistic approach to the study of metaphor. It does so by drawing on representative, naturally-occurring empirical corpus data from the argumentative written discourse of Spanish EFL undergraduate students. Few empirical studies have looked at the uses of linguistic metaphor in a corpus of EFL learner written production. While metaphorical expressions have been claimed to be used effortlessly in everyday life by ordinary people, it is still uncertain whether or not these are used by Spanish EFL learners in argumentative writing and if so, how their use is described in terms of frequencies and linguistic forms.

Thus, the overall aim of this study is two-fold. It aims at identifying and describing Spanish EFL students' use of metaphorical language in their ar-

2 Following Kövecses (2002) the term conventionalis used in the sense of well established and well entrenched. Metaphor is conventionalized "to the extent that it is automatic, effortless, and generally established as a mode of thought among members of a linguistic community" (Lakoff \& Turner, 1989, p. 55) thereby reducing our awareness of its semantic tension. gumentative written production. It has set out three specific objectives:

- To select and apply an appropriate theoretical and analytic framework for linguistic metaphor identification in naturally-occurring data,

- To determine the extent to which linguistic metaphors are used in a corpus of argumentative texts written by Spanish EFL learners, and

- To describe the linguistic form of metaphor in terms of its word-class patterns in the corpus under study.

While the first specific objective is of methodological nature, the second and third have motivated the two main research questions that guide the study reported in this article:

1. To what extent are linguistic metaphors used by Spanish EFL students in a corpus of argumentative writing?

2. What are the grammatical patterns of linguistic metaphor in the corpus under analysis?

\section{Corpus Linguistics and Corpus Data}

In order to address this methodological concern about metaphor identification and to seek answers to the proposed research questions, a corpus-driven approach to the analysis of metaphor has been adopted and a learner corpus has been used.

Corpus linguistics involves the study "of language based on examples of 'real life' language use" (McEnery \& Wilson, 1996, p. 1), that is, a methodology in which the analysis of language is based on contextualized, naturally-occurring data rather than on data that are artificial or "made-up" (Meyer, 2002, p. xiii). As stated by Lüdeling \& Kytö (2008), corpus linguistics offers a set of methods than can be used in the study of a great number of different research questions across the broad (applied) linguistics spectrum. Corpus linguistics thus provides a methodological framework to the study of metaphor interested in examining what speakers actually write rather than in hypothesizing about the ways they might or should use the language. 
The methodological approach followed in this study is corpus-driven since it places the corpus at the center of the research process and allows new categories to emerge from it. This methodology, as Tognini-Bonelli (2001) points out, differs from corpus-based work as it is characterized by having no pre-defined categories to be searched for and investigated in the corpus. The present piece of work follows a corpus-driven methodology in the sense that it has no pre-defined sets of instances of linguistic metaphors to be looked for in the corpora under investigation. The corpus-driven approach is also free of "pre-tagged texts" (Sinclair, 2004, p. 191) and so the researcher processes the raw text directly being able to observe and investigate the emergent patterns.

The main object of research in corpus linguistics is a large collection of authentic machine-readable texts (a 'body' of language) stored in an electronic database (Baker, Hardie, \& McEnery, 2006). The corpus used in the development of this study consists of argumentative essays extracted from the International Corpus of Learner English -ICLE(Granger, Dagneaux, \& Meunier, 2002). ICLE is an unannotated corpus that resulted from over 15 years of collaboration between a large number of universities from different countries.

The project was launched by Dr. Sylviane Granger at the University of Louvain-la-neuve, Belgium, in October 1990, and it aimed at providing a more solid empirical foundation for researchers interested in studying non-native varieties of English. The ICLE corpus contains 2.5 million words of English written by learners from 11 different mother tongue backgrounds, they are learners of English as a foreign language rather than Second language learners and thus, they have learned English in a non-English-speaking country and primarily in classroom settings. Based on external criteria, the students' proficiency level ranges from upperintermediate to advance.

Given that my L1 is Spanish and my professional experience as an EFL teacher-researcher has been developed in L1 Spanish contexts, the decision was made to work on the ICLE Spanish sub-corpus: SPI-
CLE. The texts in SPICLE were written by university undergraduates enrolled in the English Philology program at Unversidad Complutense de Madrid, usually in their third of four year.

The subset of SPICLE used in this study consists of 129 texts, all of them being argumentative essays. The total number of words is 82,364 ; the average essay length being 638 words. The essays were written covering different topics. Some of those topics are modern world, science and technology, the prison system, money, television, education, and crime.

\section{Procedures for Linguistic Metaphor Identification in Corpus Data}

Several procedures for linguistic metaphor identification have been proposed by metaphor researchers in response to their type of corpus, their research objectives and questions. Stefanowitsch (2006) presents a summary of the three main strategies for extracting linguistic expressions that may manifest conceptual mapping from non-annotated corpora.

One strategy consists of searching for source domain vocabulary. It consists of selecting a potential source domain (e.g., WAR, ANIMALS, COLORS, HEALTH, etc.) and then searching for individual lexical items from this domain using concordancing techniques and programs. The choice of items can be based on a priori decisions, on existing lists, or on a preceding keyword analysis of the texts dealing with.

The second strategy consists of searching for target domain vocabulary (e.g., EMOTIONS, ECONOMICS, PERCEPTION, etc.). This method requires large bodies of representative and relatively monothematic texts dealing with the target domain. Clearly these two methods will only identify a subset of metaphorical expressions, namely those that contain specific source- or target-domain vocabulary. Most researchers have used any of these two methods to conduct their empirical studies (e.g., Boers, 1999; Deignan, 2005; Koller, 2004, Partington, 2006; Semino, 2005).

Third, and most important for the development of this corpus-driven study, is manual searching. There are two main problems when using this method: it 
drastically limits the potential size of the corpus as the researcher has to carefully read throughout the corpus extracting all linguistic metaphors she or he comes across. Also, and as a consequence, this method requires manual annotation which is very demanding and takes much longer than automatic annotation.

These reasons may explain the fact that very few researchers have used this strategy in empirical studies (e.g., Cameron, 2003; Low, 2008; Semino \& Masci, 1996). However, manual searching allows for an exhaustive, in-depth search and certainly reduces the potential risk of missing significant instances of metaphorical language used in the corpus. Since one of my purposes is to determine the extent to which metaphor is used in argumentative EFL students' writing, an exhaustive search is necessary. Therefore, manual searching might be seen as the most appropriate strategy for metaphor identification in this corpus-driven study.

In order to gain understanding of the frequencies of occurrence and word-class patterns of linguistic metaphor in argumentative EFL student writing, the first task was to set clear criteria as to what could be (or could not be) counted as metaphorically used language. This was not a straightforward task and some problems emerged during the process of metaphor identification. This issue was somehow expected.

While evidence from theoretical approaches to metaphor has been taken from decontextualized, elicited, and created examples that are certainly figurative, researching metaphor in naturallyoccurring contextualized discourse has been found to be problematic by several researchers (Cameron, 1999, 2003; Heywood et al., 2002; Pragglejaz Group, 2007; Steen, 1999). In addition, few studies embark on the task of identifying all instances of metaphor through manual searching (as previously mentioned). In what follows, the linguistic metaphor identification procedure applied in this study and the ways problematic issues were dealt with will be presented and discussed.

\section{Key starting points in metaphor identification}

There is unlikely to be full consensus either on what counts as metaphor or on how much the use of a word or phrase is metaphoric. Discourse and corpus researchers have adopted different definitions and different criteria as to what can be considered an instance of linguistic metaphor or of a metaphorical linguistic expression, in CMT terms.

As Charteris-Black (2004) argues, metaphor is "a relative rather than an absolute concept" (p. 20), what is intended as a metaphor may not be interpreted as one and, as the meanings of words change over time, what was once metaphorical may now be literal. Thus, for the development of this study, it is important to define, as a starting point, what is going to be considered as an instance of linguistic metaphor.

Linguistic metaphor in this study is understood as a stretch of language that has the potential to be interpreted metaphorically (Cameron, 2003, 2006). However, as the author argues, this clear straightforward and usual placement only works with the simplest examples. The focus of this study is on instances of linguistic metaphor that may be counted (as opposed to metaphors at the conceptual level).

It refers to metaphors in language use and it includes conventionalized metaphorical language. In this regard, a prosaic view of metaphor is adopted. Prosaics is concerned with the ordinary, everyday language rather than with the artistic, poetic or special use of language (Cameron, 2003). Thus, metaphor in this study goes far beyond the ornamental or the decorative, it is concerned both with the conventional and the creative metaphorical language used in argumentative writing by ordinary people (EFL students) for everyday purposes (writing an argumentative essay).

\section{The Metaphor Identification through Vehicle terms (MIV) procedure}

Within the applied linguistics trend, Cameron (1999, 2003, 2006) has developed the Metaphor Identification through Vehicle terms (MIV) procedure for 
metaphor identification in contextualized data. The MIV sets out how to distinguish (linguistic) metaphors from non-metaphors in real contexts of use. It requires manual searching and manual annotation since the researcher might extract all the instances of linguistic metaphor present in a text. It consists of identifying the presence of a focus term, that is the Vehicle term, which is a word or phrase that somehow contrasts with (is incongruous or anomalous with) the topic of the on-going text.

The first step in metaphor identification is then to identify possible Vehicle terms that have the potential for incongruity. The incongruity can be resolved by some 'transfer of meaning' from the Vehicle (the metaphorical focus) to the Topic (the content of the on-going discourse) where 'transfer' is used in a loose sense that may be described theoretically as comparison, interaction or conceptual mapping. The second step then is to see whether connections can be made between the meaning of the Vehicle and the Topic domain. The following examples illustrate how the MIV procedure works:

Example 1 (From Cameron, 2006)

1. "I've been an active republican": active is identified as the Vehicle term. It has a meaning of being physically active that is metaphorical when used to mean politically engaged.

Example 2 (From the EFL Students' Corpus)

2. "It is a very widespread opinion": widespread is identified as the Vehicle term. It has a meaning of being physically occupying a wide space metaphorically used to mean generalized.

The MIV procedure was used in this study to identify instances of linguistic metaphor in a sample text from the EFL Students' Corpus. It required several readings of the data and reliance on the researcher's knowledge of the language and the contexts of use. It has been widely acknowledged that metaphor identification may depend on the researcher's intuitions at least to some extent. This fact makes the reliable identification of linguistic metaphor a problematic issue since the researcher may either overlook instances of linguistic metaphor or look at the data over-optimistically and inaccurately mark language as metaphorical.

Accuracy in identification was strengthened in this study by the help of four raters who checked the sample text from the corpus under study. Its usefulness went beyond a simply cross-checking of the data as it was also of significant value in the construction of a final set of linguistic metaphors for the corpus. The sample was randomly taken from the dataset and consisted of a 638-word text from the SPICLE corpus. Two of the raters were non-native speakers of English whose L1 is Spanish, and the other two were native speakers of English. All the raters were experienced metaphor researchers and they received the same sample and the same guidelines for metaphor identification through Vehicle terms.

The results of the four rounds of checking are summarized in Table 1. It shows that the 4 raters agreed on $87.3 \%$ of the data being literal on the one hand, and on $2.8 \%$ of the data being fully metaphorical on the other. In addition, it also shows that cases of disagreement among raters (those cases marked by 1,2 , or 3 of the raters) account for $9.9 \%$ of the data.

Table 1. Marking of metaphorical instances by raters in sample text

\begin{tabular}{|c|c|c|c|}
\hline $\begin{array}{c}\text { No. of Times } \\
\text { Marked by } \\
\text { Raters }\end{array}$ & $\begin{array}{c}\text { Frequency } \\
\text { (No. of words) }\end{array}$ & $\begin{array}{c}\text { Percentage } \\
\text { (\%) }\end{array}$ & \\
\hline 0 & 557 & 87.3 & \\
\hline 1 & 39 & $\mathbf{6 . 1}$ & \\
\hline 2 & 9 & $\mathbf{1 . 4}$ & $\mathbf{9 . 9 \%}$ \\
\hline 3 & 15 & $\mathbf{2 . 4}$ & \\
\hline 4 & 18 & 2.8 & \\
\hline Total & 638 & $100 \%$ & \\
\hline
\end{tabular}

Applying the MIV procedure for metaphor identification and the inter-rater checks were very important to improve reliability in this study. However, having several raters going through the same 
sample of data was revealing of the need to have a closer look at each Vehicle term marked by at least one of the raters as a potential instance of linguistic metaphor.

\section{The Metaphor Identification Procedure (MIP)}

In order to disambiguate unresolved cases (i.e., cases of disagreement) the decision was made to adapt the Metaphor Identification Procedure (MIP) proposed by the Pragglejaz Group (2007). ${ }^{3}$ The MIP is a flexible and reliable procedure that consists of four steps for metaphor identification in context. It is flexible because metaphor researchers from different fields may adapt the procedure according to their research questions and goals.

It is reliable because it goes beyond intuitive judgments from the part of the metaphor analyst. The MIP proposes the use of external resources, such as dictionaries, "as a frame of reference to check individual intuitions” (Pragglejaz Group, 2007, p. 25). Pragglejaz recommends the use of the Macmillan English Dictionary for Advanced Learners since it is a corpus dictionary based on a large and recent corpus of contemporary English. The procedure is as follows (Pragglejaz Group, 2007, p. 3):

1. Read the entire text-discourse to establish a general understanding of the meaning.

2. Determine the lexical units in the textdiscourse.

3. a.- For each lexical unit in the text, establish its meaning in context, that is, how it applies to an entity, relation, or attribute in the situation evoked by text (contextual meaning). Take into account what comes before and after the lexical unit.

b. - For each lexical unit, determine if it has a more basic contemporary meaning in other contexts than the one in the given context. For our purposes, basic meanings tend to be

3 The members of the group are senior metaphor researchers: Peter Crisp, Raymond Gibbs, Alice Deignan, Graham Low, Gerard Steen, Lynne Cameron, Elena Semino, Joe Grady, Alan Cienki, and Zoltan Kövecses.
More concrete (what they evoke is easier to imagine, see, hear, feel, smell, and taste).

- Related to bodily action;

- More precise (as opposed to vague);

- Historically older;

Basic meanings are not necessarily the most frequent meanings of the lexical unit.

c. - If the lexical unit has a more basic current-contemporary meaning in other contexts than the given context, decide whether the contextual meaning contrasts with the basic meaning but can be understood in comparison with it.

4. If yes, mark the lexical unit as metaphorical.

\section{Proposing a combination of procedures}

For the development of this study, the three parts of step 3, and step 4 of the MIP procedure, which are especially valuable for their systematic and intuitions-sharpener qualities, were used in combination with the MIV procedure for metaphor identification purposes. Thus, for each Vehicle term (VT) previously identified in the sample text, and employing the New Edition of the Macmillan English Dictionary for Advanced Learners (Rundell \& Fox, 2007), the following steps adapted from Pragglejaz Group (2007) were applied in order to determine whether each VT was used metaphorically in the context of each text:

\section{Step 3}

- Establishing the contextual meaning: For each VT in the text, establish its meaning in context. That is, how it applies to an entity, relation, or attribute in the situation evoked by the text, taking into account what comes before and after the VT.

- Establishing the basic meaning: For each VT in the text, determine if it has a more basic, 
contemporary meaning in other contexts than the one in the given context. Basic meanings tend to be:

- More concrete: what they evoke is easier to imagine, see, hear, feel, smell, and taste;

- Related to bodily action;

- More precise (as opposed to vague);

- Historically older.

- Contextual meaning vs. Basic meaning: If the VT has a more basic current, contemporary meaning in other contexts than the given context, decide whether the contextual meaning contrasts with the basic meaning but can be understood in comparison with it.

\section{Step 4}

- If yes, mark the VT as metaphorical.

By applying the procedure to one of the excerpts of the EFL students' sample text, taken from the corpus, the following three examples (cases of disagreement among raters) illustrate how the adapted steps from the MIP procedure work in combination with the MIV procedure:

Example (From the EFL Students' Corpus):

3. "people who have a great politic power, (...), always get a very good lawyer and they are pardoned most of the times, but nowadays the people are beginning to be tired of this" SP01-059

Great, power and tired were identified, by at least one of the raters, as Vehicle terms. Each VT is considered in turn and the decisions for each part of step 3 and step 4 from the MIP procedure are reported:

Great

- Contextual meaning: In this context, "great" indicates large abstract amount (of political power) and it is related to the description of important/powerful people.

- Basic meaning: The basic meaning of great emphasizes the physical size of something or someone (as in the following example from the Macmillan English Dictionary (MED) " $a$ great hole").

- Contextual meaning vs. Basic meaning: The contextual meaning contrasts with the basic meaning and can be understood by comparison with it: abstract (size/importance) can be understood by physical size.

- Metaphorically used? Yes

Power

- Contextual meaning: In this context, "power" refers to the ability to influence or control what people do or think.

- Basic meaning: The basic meaning of power relates to physical force or strength as in the example taken from the MED: "the power of the crocodile's jaws."

- Contextual meaning vs. Basic meaning: The contextual and basic meanings contrast with each other: abstract control and influence can be understood in terms of physical force and strength.

- Metaphorically used? Yes

Tired

- Contextual meaning: In this context, "tired" refers to having lost patience or interest because you have heard or seen the same thing/ issue so often.

- Basic meaning: tired has a different, more physical meaning related to the need to rest or sleep.

- Contextual meaning vs. Basic meaning: The contextual meaning contrasts with the basic meaning: a state of mind can be understood by a physical state.

- Metaphorically used? Yes 
As a result of the above qualitative analysis, the three Vehicle terms identified as instances of linguistic metaphor are judged as being used metaphorically. The previous examples are highly conventional metaphors and illustrate how the combination of procedures work and some of the decisions made when judging whether a word conveys metaphorical meaning in context.

The decision to work on a Vehicle terms basis, that is, on "words or phrases that can be justified as somehow anomalous, incongruent, or 'alien' in the ongoing discourse" (Cameron et al., 2009, p. 71), instead of looking at every single lexical unit in the text (step 2 in the MIP procedure) ${ }^{4}$ was motivated by two main reasons. Firstly, this approach (MIV) sees language in use as dynamic and acknowledges the fact that metaphorical language might be present in chunks or at phrase-levels (as can be observed in the given definition of Vehicle term). Secondly, because articles and primary auxiliary verbs, per se, might be near to semantic emptiness and therefore "it is difficult to imagine a case for their ever being metaphors" (Deignan, 2005, p. 50).

In line with the metaphor scholars who have proposed these metaphor identification procedures, I make no claims as to whether the actual writers intended their words to express metaphorical meanings; thus, the combined procedure may be understood as a systematic, reliable method that aids the researcher in the task of determining whether words in contexts convey metaphorical meaning.

This combined procedure for metaphor identification was first applied to the sample text and then piloted in one exploratory study which used over 5,500 words from each sub-corpus (Chapetón, 2008). While applying the combined identifica-

4 Note that at step 2 of the MIP procedure, as shown in Pragglejaz $(2007$, p. 4), the lexical units in the sentence are identified with slashes indicating the boundaries between each lexical unit and the procedure should be applied to each one of the lexical units in the text. While in MIP only the particles of multi-word lexical units would count as metaphorical, the identification on a Vehicle terms basis, keeps the verb and the particle together as a single Vehicle. tion procedure, it was realized that establishing the basic meaning of some words like verbs, and more particularly of prepositions, was sometimes complicated.

There are entries in the MED in which different meanings may be conflated under the same meaning description. As Steen et al. (forthcoming) have observed, MED sometimes combines abstract and concrete senses, animal and human senses, or inanimate and animate senses. In such cases, I also used The Shorter Oxford English Dictionary on Historical Principles -SOEDHP- (Little, Fowler, Coulson, \& Onions, 1973) which provided me with supplementary information about etymology useful to establish basic meanings. My decision to use SOEDHP was motivated by the fact that Pragglejaz Group (2007) and Skorczynska \& Deignan (2006) have also used it in their metaphor analyses.

In order to strengthen the accuracy of the decisions as regards prepositions, Lindstromberg (1998) was used as an additional resource. His book English Prepositions Explained proved to be extremely useful as it discusses both the central, prototypical and most basic meanings of each preposition and the cases in which they have metaphorical extensions of meaning. The following are illustrative examples of common metaphorical uses of the preposition of place in:

1. “This novel was published in 1866." SP02060

2. “...we live in a continuous hurry," SW34115

3. “...killed in a quarrel.” SP16-074

This preposition shows significant Topic variation since it is used to talk about time (citation 4), manner (as in 5), or circumstances (as in 6). These metaphorical uses of prepositions have been addressed in CMT. In their discussion of conceptual metaphors, Lakoff \& Johnson (1980), Lakoff \& Turner (1989), and Lakoff (1993) point out facts related to the examples above: time is conceptualized in terms of space (example 4), states are conceptualized in terms of locations or bounded regions in space (example 
5), and circumstances are conceptualized in terms of places (example 6).

The process of metaphor identification in naturally-occurring contextualized argumentative writing required the consideration of several complex issues that somehow emerged from actually working with the data. First, the unit of analysis was defined as the countable linguistic metaphor that has the potential to be interpreted metaphorically, including conventionalized metaphorical language.

Second, the identification through Vehicle terms was set as a fundamental first step to distinguish (linguistic) metaphors from non-metaphors in real contexts of use. Third, for reliability purposes, interrater procedures were applied to a sample text from the corpus used in the development of this study. Finally, a combination of procedures for metaphor identification (MIV and MIP) was effective and helpful in going beyond intuitive judgments by a) making systematic decisions and b) using key resources as frames of reference.

\section{The presence of metaphor in Spanish EFL writing and its word class}

With the application of a combined procedure for metaphor identification as described above, I aimed at manually extracting all instances of linguistic metaphor in the corpus in a systematic, rigorous, and reliable way. However, it was soon realized that applying such a procedure to the whole corpus $(82,364$ words) was a colossal task for a sole researcher. In view of such hurdle, the decision was made to apply the combined identification procedure to $25 \%$ of the whole data $(20,602$ words).

Therefore, complete texts from the Spanish EFL students' corpus were randomly selected from each one of the topic groups, in similar proportions, to build a 'core' corpus (Semino, 2002) which was analyzed in detail for instances of linguistic metaphor. The remaining material was not analyzed in detail for manual metaphor identification, but was subjected to selected concordance searches aimed at examining the general validity of the analyses and findings of the manually coded corpus.
The quantitative analysis indicates the frequencies and percentages of literal and metaphorical language in the corpus. The results shown in Table 2 illustrate that $19.8 \%$ of the language used in the Spanish EFL students' corpus is metaphorical while $80.2 \%$ is literal.

Table 2. Overall Metaphor Density in the corpus

\begin{tabular}{|l|c|c|}
\hline & Frequency & Percentage \\
\hline literal & 16,532 & 80.2 \\
\hline metaphorical & 4,070 & 19.8 \\
\hline Total & 20,602 & 100.0 \\
\hline
\end{tabular}

The manual identification of instances of linguistic metaphor in the core data was accompanied and followed by a process of metaphor coding. Each identified metaphor was analyzed for word class (i.e., part of speech). Word-class metaphor coding was manually done while in the process of manually identifying instances of linguistic metaphor in the texts. Therefore, MED was used as a resource in this regard as well. However, in cases in which I was uncertain, I made use of the CLAWS 5 tagger, a word-tagging system which automatically assigns part-of-speech tags to the words in a given text indicating their word-class membership.

Two main word-class categories emerged from the analysis of the data: a) Single word instances of linguistic metaphor, classified and coded according to the word class to which the Vehicle term belonged (noun, verb, adjective, adverb, and preposition), and b) Phrase level and multi-word Vehicle terms, classified by the word class of the head word in the phrase. Table 3 shows the classification followed in the present study along with illustrative examples from the corpus data.

5 CLAWS is available from http://www.comp.lancs.ac.uk/computing/ research/ucrel/claws/ 
Table 3. The Word Class Categorization of Metaphor

\begin{tabular}{|c|c|c|c|}
\hline \multirow{5}{*}{$\begin{array}{l}\text { Single word } \\
\text { instances } \\
\text { of linguistic } \\
\text { metaphor }\end{array}$} & Noun & $\begin{array}{l}\text { A word that refers to a person, place, thing, event, subs- } \\
\text { tance or quality. }\end{array}$ & Economical damage. \\
\hline & Adjective & A word that describes qualities of a noun or pronoun. & A very widespread opinion. \\
\hline & Verb & A word that describes an action, state or process. & Crime pays. \\
\hline & Adverb & $\begin{array}{l}\text { A word that describes or gives more information about a } \\
\text { verb, adjective, another adverb or phrase. }\end{array}$ & $\begin{array}{l}\text { [...] Minorities have waited long } \\
\text { enough. }\end{array}$ \\
\hline & Preposition & $\begin{array}{l}\text { A word which is used before a noun, a noun phrase or a } \\
\text { pronoun, connecting it to another word or phrase. }\end{array}$ & $\underline{\text { In }}$ our modern time. \\
\hline \multirow{4}{*}{$\begin{array}{l}\text { Multi-word } \\
\text { instances } \\
\text { of linguistic } \\
\text { metaphor }\end{array}$} & Noun phrase & $\begin{array}{l}\text { A phrase that consists of a noun as head accompanied by } \\
\text { determiners or modifiers. }\end{array}$ & The starting point. \\
\hline & Verb phrase & $\begin{array}{l}\text { A phrase that consists of a verb as head plus accompan- } \\
\text { ying elements, including objects and predicatives. }\end{array}$ & People who play by the rules. \\
\hline & $\begin{array}{l}\text { Multi-word lexical } \\
\text { verbs (MWLV) }\end{array}$ & $\begin{array}{l}\text { This category (after Biber et al., 1999) includes instances } \\
\text { of a) lexical verbs followed by an adverbial particle (phrasal } \\
\text { verbs); b) lexical verbs followed by a preposition (prepo- } \\
\text { sitional verbs) and c) lexical verbs which contain both an } \\
\text { adverbial particle and a preposition, as in get away with. } \\
\text { (phrasal-prepositional verbs). }\end{array}$ & Ideologies lie behind. \\
\hline & $\begin{array}{l}\text { Prepositional } \\
\text { phrase }\end{array}$ & $\begin{array}{l}\text { A phrase consisting of a preposition and a complement, } \\
\text { most typically in the form of a noun phrase. }\end{array}$ & At the doors of the 21 st century. \\
\hline
\end{tabular}

By breaking the quantitative evidence down into word classes, it is possible to explore whether Spanish EFL students' argumentative writing might be based on a nominal, verbal, prepositional, or adjectival model as far as the grammatical form of metaphor concerns. The results show that two single word-class categories stand out with values over 20 per cent: single verbs with $27.4 \%$ and prepositions with $26 \%$. As shown in Figure 1 below, single word nouns, which are often used to exemplify metaphor theory, rank third and account for 19.3\%. Linguistic metaphors with adjectives follow with $11.1 \%$. The two least frequent categories are verb phrases and adverbs with $1.8 \%$ each.

Figure 1. Word-class distribution of linguistic metaphors in the Spanish EFL corpus

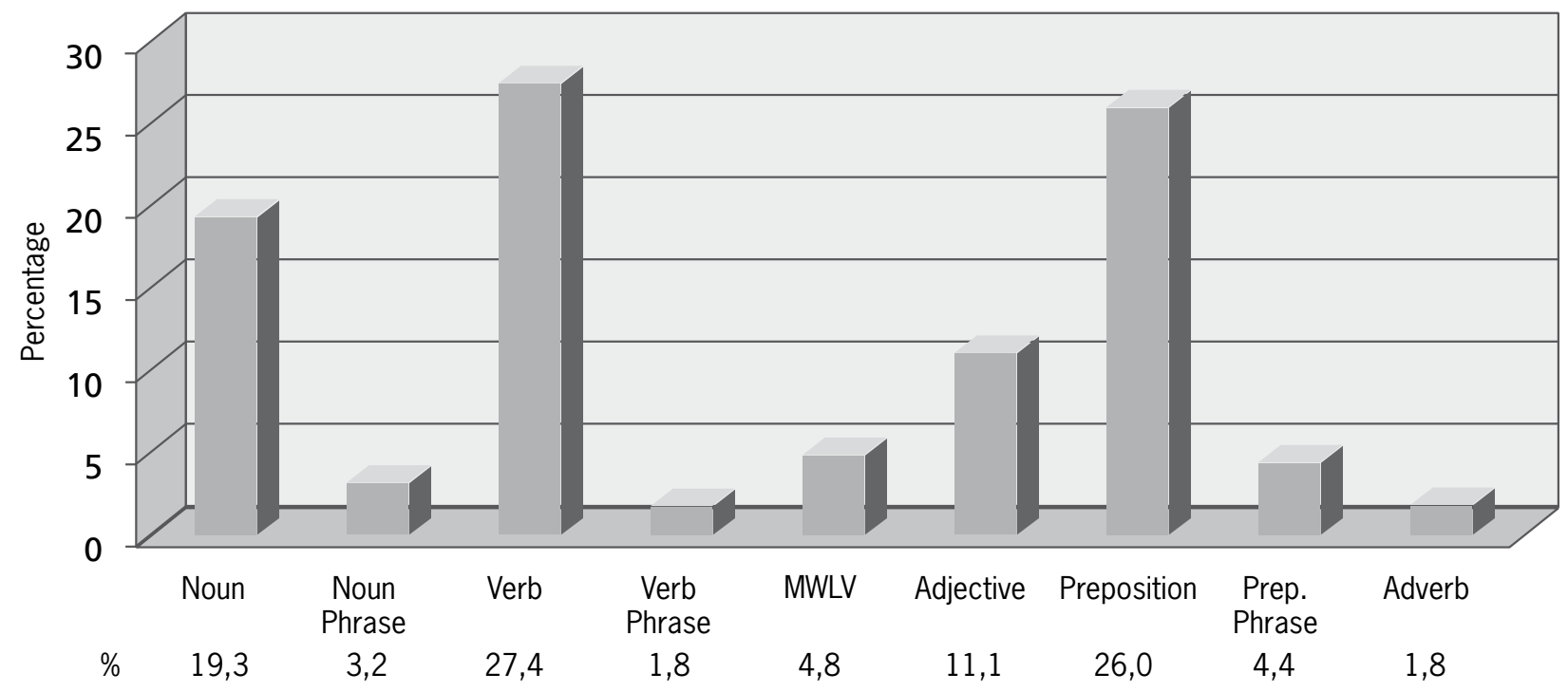


A further feature that characterizes the nature of linguistic metaphor in the Spanish EFL students' corpus is the presence of misused items. Even if a needs analysis was not initially considered as part of the scope of this study, the decision to identify non-native-like instances involved in the use of linguistic metaphor was made during the very process of data coding as it emerged as an issue worth consideration.

This by no means is intended to be a comprehensive error analysis. I do not claim that all the potential non-native-like instances or foreign-sounding constructions involved in linguistic metaphor are accounted for in this exploration. Neither I assume that all the misused items identified here are caused by conceptual or cognitive transfer, "notably, errors could also result from other causes and thus cannot necessarily serve as proof of conceptual transfer; they may, however, be numbered among its manifestations" (Jarvis \& Pavlenko, 2008, p. 142).

Still, the identification of non-native-like instances may shed some light on the most salient difficulties faced by learners when producing (consciously or unconsciously) instances of linguistic metaphor. Table 4 provides an overview of the overall frequencies of non-native-like occurrence identified during the process of manually coding the data for linguistic metaphors. They are grouped by word class:

Table 4. Word Class Distribution of Misused Metaphors in the Spanish EFL corpus

\begin{tabular}{|l|c|c|}
\hline \multicolumn{1}{|c|}{ Word Class } & Occurrences & \% \\
\hline Noun & 9 & 8.4 \\
\hline Verb & 9 & 8.4 \\
\hline Verb Phrase & 4 & 3.7 \\
\hline MWLV & 5 & 4.7 \\
\hline Preposition & $\mathbf{7 5}$ & 70.1 \\
\hline Prepositional Phrase & 4 & 3.7 \\
\hline Adverb & 1 & 0.9 \\
\hline Total & $\mathbf{1 0 7}$ & $\mathbf{1 0 0 . 0}$ \\
\hline
\end{tabular}

The above results seem to indicate that difficulties associated with prepositions might be the most salient. If grouped with multi-word lexical verbs, whose particles involve prepositions, and with prepositional phrases, these account for $79.3 \%$ of the identified data. Moreover, a closer look at the non-native-like instances of linguistic metaphor grouped under the verb phrase category reveals that 3 of them also involve misused prepositions:

4. * "take a look to" SH13-024

5. * "taken in consideration" SF11-011

6. * "bring into life" SW06-087

With regard to prepositional phrases, the most salient feature has to do with the cohesive device "on the other hand". The preposition slot was mistakenly filled with the prepositions in or by in productions like:

7. * "In the other hand" SP16-074

8. * "By the other hand," SP01-59

9. * "in one hand" SW44-125

Three out of the five multi-word lexical verbs identified involve the preposition in: $\left({ }^{*}\right.$ base in, ${ }^{\star}$ traduce in, ${ }^{*}$ turn in), and as far as single prepositions are concerned, misuses of in are the most prevailing (27 instances) followed by to (with 17) and on (with 10).

The fact that prepositions in English can be troublesome for EFL learners is not surprising news. However, these observations may support Lindstromberg's (1998) argument for the need to unveil the system and logic behind the complexity of prepositional collocation by drawing the distinctions and similarities between the literal and metaphorical to see how those meanings are related.

Significant work has been done on describing how different spatial senses of prepositions are metaphorically extended from a central sense (or prototype) in quite systematic ways (e.g., Boers, 1996; and Lindstromberg, 1998), and notably by Kövecses \& Szabó (1996), Lindstromberg (1996), Boers \& Demecheleer (1998), and Cho (in press) on proposing pedagogical approaches that borrow insights from CMT to draw EFL learners' attention on the metaphorically motivated uses of these polysemous items. 
Their work has suggested that by tracing the metaphorical connections between the abstract and concrete senses of prepositions, learners are helped to realize "that the figurative use of English prepositions is far more systematic than is often assumed" (Boers \& Demecheleer, 1998, p. 203). More recently, work by Cho (in press) within the applied cognitive linguistics approach, has shown that Japanese EFL students benefit significantly from classroom instruction that clarifies how the various usages of the English prepositions in, on and at are motivated extensions from a prototypical sense.

An observation of the nouns and verbs that were identified as misused linguistic metaphors reveals that the item lose/losing/lost prevails. This is illustrated in the following citation:

\section{0. ${ }^{\star} “ .$. this loses of time...” SE12-050}

As this example shows, the wrong choice of the noun might be explained by factors such as L1 transfer. In Spanish, time is seen as gold, as in " $e l$ tiempo es oro". Gold is a valuable object that can be lost. By contrast, in English, time is conceptualized in terms of money which can be wasted. As pointed out by Jarvis \& Pavlenko (2008), differences in ways of thinking about and framing particular aspects of the world around us, that is conceptualization differences, might result in L2 users' reliance on the frames favored in the source language when using the target language, which in this case are Spanish and English respectively.

In addition, cases as the one illustrated in citation (13) above might be related to collocational patterns as well. In his discussion of factors which influence the process of collocation in EFL contexts, Walker (2008) includes metaphor as one of the most important. His corpus-based examination of the items aim, objective, target, goal, deal with and handle, which are difficult for German EFL learners, led him to suggest that "features associated with the literal sense of an item may restrict the way in which that item is used metaphorically" (Walker, 2008, p. 300). It would appear then, that Spanish EFL learners' might be benefited if the complexities of collocation in English were meaningfully and conceptually unveiled.

\section{Conclusions}

The first specific objective stated at the outset was of methodological nature and was motivated by the well known concern for reliable, systematic, and valid procedures for metaphor identification in contextualized data which should provide a clear account of what is and is not considered metaphorical.

As I embarked on the task of identifying all instances of linguistic metaphor through manual searching in the core corpora under study, I started to face a number of problematic issues and I realized that a combination of procedures was appropriate to provide systematic solutions to those emergent problems. I have thus piloted, applied, and developed a methodology for metaphor identification that combines the MIV and the MIP procedures. Both, the search through Vehicle terms and the inter-rater checks combined with the intuitions-sharpener steps of the MIP, proved to be a valid and reliable procedure for metaphor identification in real contexts of language use.

In response to the first research question asking about the extent to which linguistic metaphors are used by Spanish EFL students in their argumentative writing, it can be said that most of the language used by these students is literal while metaphors account for less that $20 \%$. This is not surprising, as Hanks (2006) argues, "Metaphorical uses cannot be too frequent. Frequency breeds literalness." (p. 21). However, this is an important finding that shows that metaphorical language goes beyond the artistic and decorative, that it is highly conventional, and that it can be present in the argumentative writing produced by non-native speakers of the language.

The second research question guiding this study asked about the grammatical patterns of linguistic metaphor in the corpus under study. The analysis revealed that metaphors with single verbs as Vehicle terms are the most common form and that these are closely followed by single prepositions. The conventionality of the metaphorically extended meanings of these two word-class categories can serve to explain 
their high frequencies of use in the corpus. The fact that metaphors with single nouns as Vehicle terms ranked third and accounted for less than 20 per cent of the data, may have theoretical implications as they are often used to exemplify metaphor theory, as Deignan (2005) points out, the differences in form are not fully explained by the relatively static view of mapping that is sometimes suggested in discussion of Conceptual Metaphor Theory.

In addition, it was shown that the use of linguistic metaphor by Spanish EFL students might involve non-native-like features. An exploration of these instances revealed that these are found in the different word-class categories analyzed in this study and hence they all should receive pedagogical attention.

However, it is instances of linguistic metaphors involving prepositions (at single, multi-word and phrase levels) the ones that appear to pose the most problems. This suggests the need to prioritize attention towards these particularly polysemous items. Spanish EFL students might need to be helped to unveil the links between the literal/concrete and metaphorical/abstract senses of prepositions so that they are able to realize the motivated and systematic nature that lies behind the complexities of prepositional collocation in the target language. Applied cognitive research in this area might serve a great deal towards this end.

Future research should also involve the use of native comparable corpora that can inform about frequencies of use, word-class patterns, and lexical content, and reveal differences and similarities in the use of linguistic metaphor in similar contexts of use by native and non-native speakers of the language. 


\section{References}

Baker, P., Hardie, A., \& McEnery, T. (2006). A Glossary of Corpus Linguistics. Edinburgh: Edinburgh University Press Ltd.

Biber, D., Johansson, S., Leech, G., Conrad, S., \& Finegan, E. (1999). Longman Grammar of Spoken and Written English. London: Longman.

Boers, F. (1996). Spatial Prepositions and Metaphor: A cognitive semantic journey along the up-down and the frontback dimensions. Tubingen: Gunter Narr Verlag.

Boers, F. (1999). When bodily source domain becomes prominent: the joy of counting metaphors in the socio-economic domain. In R. Gibbs \& G. Steen (Eds.), Metaphor in Cognitive Linguistics (pp. 47-56). Amsterdam: John Benjamins Publishing Company.

Boers, F., \& Demecheleer, M. (1998). A cognitive semantic approach to teaching prepositions. English Language Teaching Journal, 52(3), 197-204.

Cameron, L. (1999). Identifying and describing metaphor in spoken discourse data. In L. Cameron \& G. Low (Eds.), Researching and Applying Metaphor (pp. 105132). Cambridge: Cambridge University Press.

Cameron, L. (2003). Metaphor in Educational Discourse. London: Continuum.

Cameron, L. (2006). MetNet Group: The Metaphor Analysis Project. Retrieved from http://creet.open.ac.uk/ projects/metaphor-analysis/index.cfm

Cameron, L., \& Low, G. (Eds.). (1999). Researching and Applying Metaphor. Cambridge: Cambridge University Press.

Cameron, L., Maslen, R., Todd, Z., Maule, J., Stratton, P., \& Stanley, N. (2009). The Discourse Dynamics Approach to Metaphor and Metaphor-Led Discourse Analysis. Metaphor and Symbol, 24(2), 63-89

Chapetón, C.M. (2008). Linguistic Metaphor in Argumentative Writing (Unpublished Research Paper presented to obtain the Diploma de Estudios Avanzados -DEA-), PhD Program in Applied Linguistics at the University of Barcelona, Barcelona.

Charteris-Black, J. (2004). Corpus Approaches to Critical Metaphor Analysis. Hampshire and New York: Palgrave Macmillan.

Cho, K. (in press). Fostering the acquisition of English prepositions by Japanese learners with networks and prototypes. In S. De Knop, T. De Rycker \& F.
Boers (Eds.), Fostering Language Teaching Efficiency through Cognitive Linguistics (pp. 259-275). Berlin: Mouton de Gruyter.

Danesi, M. (1993). Metaphorical competence in second language acquisition and second language teaching: The neglected dimension. In J. E. Alatis (Ed.), Language, Communication and Social Meaning (pp. 489-500). Washington, DC: Georgetown University Press.

Danesi, M. (1994). Recent Research on Metaphor and the Teaching of Italian. Italica, 71(4), 453-464

Deignan, A. (2005). Metaphor and Corpus Linguistics. Amsterdam/Philadelphia: John Benjamins.

Deutscher, G. (2005). The Unfolding of Language. United Kingdom: Arrow Books.

Glucksberg, S. (2001). Understanding Figurative Language: From Metaphors to Idioms. Oxford: Oxford University Press.

Granger, S., Dagneaux, E., \& Meunier, F. (Eds.). (2002). International Corpus of Learner English Handbook. Louvain: Université Catholique de Louvain Press.

Hanks, P. (2006). Metaphoricity is gradable. In A. Stefanowitsch \& S. Gries (Eds.), Corpus-Based Approaches to Metaphor and Metonymy (pp. 17-35). Berlin: Mouton de Gruyter.

Heywood, J., Semino, E., \& Short, M. (2002). Linguistic metaphor identification in two extracts from novels. Language and Literature, 11(1), 35-54.

Jarvis, S., \& Pavlenko, A. (2008). Crosslinguistic Influence in Language and Cognition. New York: Routledge.

Koller, V. (2004). Metaphor and Gender in Media Business Discourse: A Critical Cognitive Study. Basingstoke: Palgrave Macmillan.

Kövecses, Z. (2002). Metaphor: A Practical Introduction. Oxford: Oxford University Press.

Kövecses, Z., \& Szabó, P. (1996). Idioms: A view from Cognitive Semantics. Applied Linguistics, 17, 326-355.

Lakoff, G. (1987). Women, fire, and dangerous things. What categories reveal about the mind. Chicago/ London: The University of Chicago Press.

Lakoff, G. (1993). The contemporary theory of metaphor. In A. Ortony (Ed.), Metaphor and Thought (pp. 202251). Cambridge: Cambridge University Press.

Lakoff, G., \& Johnson, M. (1980). Metaphors We Live By. Chicago: The Chicago University Press. 
Lakoff, G., \& Turner, M. (1989). More than cool reason: A field guide to poetic metaphor. Chicago: Chicago University Press.

Lindstromberg, S. (1996). Prepositions: meaning and method. ELT Journal, 50(3), 225-236.

Lindstromberg, S. (1998). English Prepositions Explained. Amsterdam: John Benjamins.

Little, W., Fowler, H.W., Coulson, J., \& Onions, C. T. (Eds.). (1973). The Shorter Oxford English Dictionary on Historical Principles. Oxford: Oxford University Press.

Littlemore, J. (2001). Metaphoric Competence: A Language Learning Strength of Students with a Holistic Cognitive Style? Tesol Quarterly, 35(3), 459-491.

Littlemore, J., \& Low, G. (2006). Metaphoric competence, second language learning, and communicative language ability. Applied Linguistics, 27(2), 268-294

Low, G. (2008). Metaphor and positioning in academic book reviews. In M.S Zanotto, L. Cameron, \& M. Cavalcanti (Eds.), Confronting Metaphor in Use: An applied linguistic approach (pp. 79-100). Amsterdam/ Philadelphia: John Benjamins Publishing Company.

Lüdeling, A., \& Kytö, M. (Eds.). (2008). Corpus Linguistics: An International Handbook. Berlin/New York: Walter de Gruyter.

McEnery, T., \& Wilson, A. (1996). Corpus linguistics. Edinburgh: Edinburgh University Press.

Metaphor. (n.d.). In The Oxford Dictionary of English (revised edition, 2005), Oxford Reference Online, Oxford University Press.

Meyer, C. (2002). English Corpus Linguistics: An Introduction. Cambridge: Cambridge University Press.

Partington, A. (2006). Metaphors, motifs and similes across discourse types: Corpus-Assisted Discourse Studies (CADS) at work. In A. Stefanowitsch \& S. Gries (Eds.), Corpus-Based Approaches to Metaphor and Metonymy (pp. 267-304). Berlin: Mouton de Gruyter.

Pragglejaz Group. (2007). MIP: A method for identifying metaphorically used words in discourse. Metaphor and Symbol, 22(1), 1-39.
Rundell, M., \& Fox, G. (Eds.). (2007). Macmillan English Dictionary for Advanced Learners New Edition. Oxford UK: Macmillan Education.

Semino, E. (2002). A sturdy baby or a derailing train? Metaphorical representations of the euro in British and Italian newspapers. Text, 22(1), 107-139.

Semino, E. (2005). The metaphorical construction of complex domains: The case of speech activity in English. Metaphor and Symbol, 20(1), 35-70.

Semino, E. (2008) Metaphor in Discourse. Cambridge: Cambridge University Press.

Semino, E., \& Masci, M. (1996). Politics in Football: Metaphor in the discourse of Silvio Berlusconi in Italy. Discourse and Society, 7, 243-269.

Sinclair, J. (2004). Trust the Text: Language, Corpus and Discourse. London: Routledge.

Skorczynska, H., \& Deignan, A. (2006). Readership and Purpose in the Choice of Economics Metaphors. Metaphor and Symbol, 21(2), 87-104.

Steen, G. (1999). Metaphor and discourse: Towards a linguistic checklist for metaphor analysis. In L. Cameron \& G. Low (Eds.), Researching and Applying Metaphor (pp. 81-104). Cambridge: Cambridge University Press.

Stefanowitsch, A. (2006). Corpus-Based approaches to metaphor and metonymy. In A. Stefanowitsch \& S. Gries (Eds.), Corpus-Based Approaches to Metaphor and Metonymy (pp. 1-16). Berlin/New York: Mouton de Gruyter.

Tognini-Bonelli, E. (2001). Corpus Linguistics at Work. Amsterdam/Philadelphia: John Benjamins.

Walker, C. (2008). Factors which influence the process of collocation. In F. Boers \& S. Lindstromberg (Eds.), Cognitive Linguistic Approaches to Teaching Vocabulary and Phraseology (pp. 291-308). Berlin/New York: Mouton de Gruyter.

Zanotto, M.S., Cameron, L., \& Cavalcanti, M. (Eds.). (2008). Confronting Metaphor in Use: An applied linguistic approach. Amsterdam/Philadelphia: John Benjamins. 